\title{
DIGITAL TECHNOLOGY AS A TOOL FOR SCHOOL CHEATING IN HIGH SCHOOLS
}

Jarmila HONZÍKOVÁ*, Západočeská univerzita v Plzni, Česká republika Petr SIMBARTL, Západočeská univerzita v Plzni, Česká republika Ján BAJTOŠ, Vysoká škola DTI, Slovenská republika

Přijato: 12. 5. 2020/ Akceptováno: 24. 8. 2020

Typ článku: Výzkumná studie

DOI: $10.5507 /$ jtie.2020.015

Abstract: The issue of school cheating has been a very current and discussed topic since the second half of the last century. The existing modern technologies and, in fact, an unlimited students' access to the Internet provide new opportunities to get learning materials, to make their studies easier. At the same time, these possibilities allow students to find new ways to cheat in the school environment. The cheating range, using information and communication technology, is really wide, from commonly used computers up to smartwatch. To the question, what school cheating opportunities are preferred by high school students in the Czech Republic, Slovakia and Poland, we are trying to find out in our research study.

Key words: school cheating, digital technology, high school students

\section{DIGITÁLNÍ TECHNOLOGIE JAKO NÁSTROJ ŠKOLNÍHO PODVÁDĚNÍ NA STŘEDNÍ ŠKOLE}

Abstrakt: Problematika školního podvádění je velmi aktuálni a diskutované téma již od druhé poloviny minulého století. Současné moderni technologie a v podstatě neomezený prístup studentů $k$ internetu poskytuji nové možnosti kziskávání učebnich materiálù, které jim usnadñují učení. Zároveñ tyto možnosti umožňují studentům najit nové způsoby, jak ve školním prostředi podvádět. Škála podváděni pomocí informačně komunikačnich prostředků je poměrně široká, od běžných počitačů až po smartwatch, neboli chytré hodinky. Na otázku, jaké zpưsoby školniho podváděni preferuji studenti střednich škol v Čechách, na Slovensku a v Polsku, se pokusíme odpovědèt v naši výzkumné studii.

Klíčová slova: školní podvádění, digitální technologie, studenti středních škol

*Autor pro korespondenci: jhonziko@kmt.zcu.cz 


\section{1 Úvod}

Školní prostředí a chování žáků ve školách je častým tématem mnoha výzkumů. Dlouho diskutovanou otázkou, a tudíž i tématem mnoha výzkumů je i otázka školního podvádění. Školní podvádění je v podstatě tak staré, jako škola sama. S vývojem společnosti a v závislosti na rozvoji technickém rozvoji se mění i metody a formy školního podvádění. Všechny definice školního podvádění se shodnou vždy na základní myšlence, že se jedná o nečestné, většinou předem promyšlené chování, které ke kterému žák přistupuje za účelem získání lepších výsledků např. (Bajtoš, Marhenková, 2016; Vrbová, Stuchlíková, 2012; Mareš, 2005). Výzkum v rámci projektu KEGA číslo projektu č.001DTI-4/2018, „School cheating as a problematic aspect of educational process assessment of the results at secondary schools" jehož hlavním řešitelem je prof. Ing. Ján Bajtoš, CSc, PhD, se zaměřil nejen na metody a formy školního podvádění na středních školách v Česku, na Slovensku a v Polsku, ale také na názory studentů a učitelů na školní podvádění, na motivy školního podvádění, a to v několika souvislostech. Výsledky tohoto velmi rozsáhlého mezinárodního výzkumu budou průběžně prezentovány. V naší výzkumné studii se zaměříme pouze na jednu část tohoto rozsáhlého výzkumu, a to na využívání digitálních technologií při školním podvádění na středních školách ve tř̌ech výše jmenovaných státech.

\section{Teoretická východiska výzkumu}

Výsledky analýzy současného stavu informací o školním podvádění nám daly odpověd' na otázku, kteří autoři prováděli výzkum na téma školní podvádění a k jakým výsledků došli.

Z českých výzkumníků se problematice školního podvádění věnoval prof. Mareš (2005). Ve svých studiích určil metody a formy školního podvádění a ve své studii Tradiční a netradiční podvádění ve škole se zabýval také elektronickým podváděním. Byl jedním z prvních autorů, který se pokusil určit podoby elektronického podvádění. Mezi hlavní typy zařadil podvádění opírající se o získávání nebo vyžadování informací, podvádění opírající se o práci s nepovolenými materiály nebo o nepovolený způsob práce s parametry a podvádění ovlivňující průběh zkoušení a hodnocení.

Typy školního podvádění mezi českými žáky zkoumala Vrbová (2012). která se zabývala typy školního podvádění a otázkou, zda je podvádění asociované s některou z vybraných charakteristik žáka (pohlaví, prospěch, školní absence). Ani ve světě není téma školního podvádění opomíjeno. Definováním pojmu školní podvádění se zabýval např. Cizek (2003), Simkin a McLeod (2010) a svými výzkumy dokazují, že podvádění je dopředu promyšlené, záměrné a úmyslné jednání. Podle autorek Norman a Harris (1981) je příčinnou školního podvádění tlak, který je vyvíjený na žáky, aby měli dobré známky. Techniky podvádění zkoumali Garavalia et al. (2007), kteří zároveň došli k závěru, že techniky podvádění na základní škole se liší od technik, které používají studenti středních škol. Metodami školního podvádění se zabývali ve svých pracích i další autoři, např. Kumar (2002), Eisenberg (2004), či Bernardi et al. (2008). Někteří autoři se ve svých výzkumech zaměřili také na elektronické formy podvádění, např. Clark (2008), Bajtoš a Marhenková (2016). 
Bajtoš a Marhenková (2016) došli ve svém výzkumu k závěru, že studenti slovenských středních škol využívají při svém podvádění nejčastěji vlastnoručně napsaný tahák (tab. $1)$.

\begin{tabular}{|c|c|c|c|c|c|c|}
\hline 䒕 & Spôsob podvádzania & $\begin{array}{l}\text { Ŝtátne } \\
\text { SOŠ }\end{array}$ & $\begin{array}{l}\text { Štátne } \\
\text { gymnázia }\end{array}$ & $\begin{array}{c}\text { Súkromné } \\
\operatorname{sos}\end{array}$ & $\begin{array}{c}\text { Cirkevné } \\
\text { stredné } \\
\text { skoly }\end{array}$ & $\begin{array}{c}\text { Vážený } \\
\text { aritmetický } \\
\text { priemer } \\
\text { celkom }\end{array}$ \\
\hline 1. & Vlastný rukou písaný tahák & 3,11 & 3,02 & 2,89 & 2,98 & 3,01 \\
\hline 2. & Vytlačený (požičaný) tahák & 3,09 & 3,00 & 2,89 & 2,85 & 2,98 \\
\hline 3. & Opisovanie $\mathrm{z}$ knihy, zošita & 3,01 & 2,48 & 2,35 & 2,76 & 2,66 \\
\hline 4. & Žiadost o našepkanie & 2,91 & 2,31 & 2,53 & 2,29 & 2,57 \\
\hline 5. & Opisovanie od spolužiaka & 2,96 & 2,45 & 2,16 & 2,41 & 2,55 \\
\hline 6. & Využitie mobilu & 2,13 & 2,98 & 2,88 & 2,14 & 2,54 \\
\hline & Celkom & & & & & 2,69 \\
\hline
\end{tabular}

Tab. č. 1: tabulka způsobio podvádění (převzato z Bajtoš a Marhenková (2016)

\section{Cíle výzkumu a použité metody}

\section{Cíle dotazníkového šetření}

Cílem celého rozsáhlého výzkumu bylo zjistit nejen hlavní nástroje podvádění, ale také motivy podvádění, postoje studentů a učitelů ke školnímu podvádění. V této studii se zaměŕme pouze na část výzkumu, jejímž cílem bylo zjistit

- $\quad$ zda studenti středních škol v Česku, na Slovensku a v Polsku, používají při školním podvádění více digitální technologie, jako jsou např. smartphone chytrý telefon a smartwatch - chytré hodinky než papírové taháky.

Využití počítačů jsme záměrně vynechali, nebot’ pro písemné a ústní zkoušení se na středních školách využívají pouze sporadicky.

$\mathrm{V}$ naší výzkumné studii se zaměřme na prezentaci výsledků $\mathrm{z}$ ověřování pouze jedné hypotézy:

H - Studenti stř̌edních škol využívají při školním podvádění více digitální technologie (mobilní telefon, smartphone, smartwatch - chytré hodinky) než papírové taháky.

\section{Výzkumný vzorek}

Příležitostným výběrem bylo vybráno 907 studentů středních škol ze Slovenska, Česka a Polska. Jednalo se o státní, soukromé, odborné školy a gymnázia. Bohužel se nepodařilo získat vyrovnané vzorky z každého státu, ponejvíce respondentů bylo ze Slovenska (623), z Česka (155) a z Polska (129). 


\section{Výzkumné metody}

- $\quad$ analýza poznatků z dostupných zdrojů

- dotazníkové šetření

Pro dotazníkové šetření byl sestaven vícepoložkový anonymní dotazník. Dotazník byl distribuován ve třech jazycích přes Google formuláře.

Pro účely této výzkumné studie jsme se zaměřili pouze na odpovědi na tři otázky z dotazníku pro studenty středních škol, které se týkaly používání mobilního telefonu, smartwatch - chytrých hodinek a klasického taháku při školním podvádění. Protože studenti měli možnost zvolit několik možností, tzn. nelze porovnávat pouze počty odpovědí, proto jsme zvolili prezentaci výsledků v procentech.

\section{Výsledky výzkumného šetření}

Výsledky odpovědí prezentujeme v pořadí: otázka, tabulka hodnot (počet), graf četností, tabulka kladných odpovědí, a to vždy v porovnání pro jednotlivé státy. Pro jednodušší a přehlednější prezentaci výsledků jsme upustili od statistického zpracování dat.

Otázka: Když při výuce podvádíte, používáte k podvádění mobilní telefon?

\begin{tabular}{|l|l|l|l|}
\hline Mobilní telefon & Cesko & Slovensko & Polsko \\
\hline téměř vždy & 8,3 & 10,3 & 21,2 \\
\hline často & 6 & 13,6 & 10,6 \\
\hline občas & 31 & 18,6 & 13,6 \\
\hline Ž̌idka kdy & 29,8 & 28,6 & 16,7 \\
\hline nikdy & 25 & 28,8 & 37,9 \\
\hline
\end{tabular}

Tab. č. 2: Využivání mobilního telefonu při školním podvádění v \%

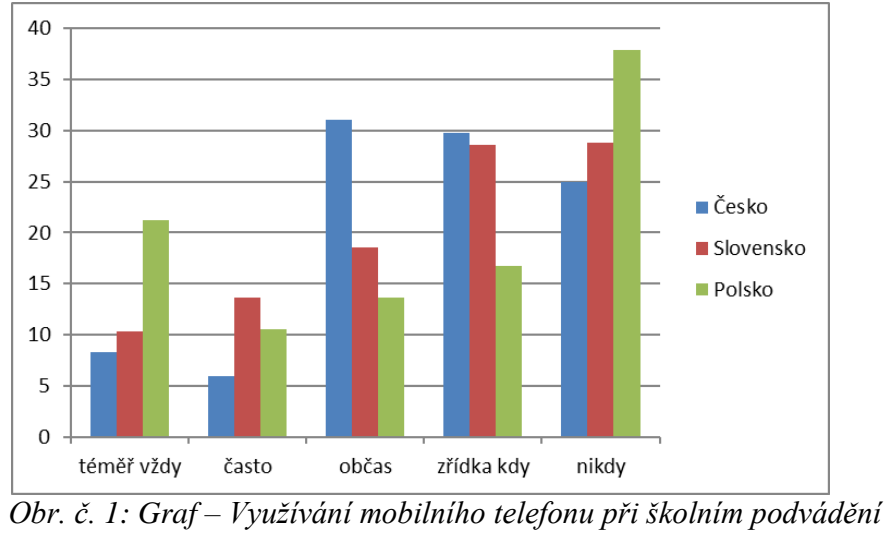


Z dotazníkového šetření vyplynulo, že mobilní telefon použivá při podvádění průměrně $44 \%$ studentů. $Z$ odpovědí vyplynulo, že při školním podvádění využívají mobilní telefony ponejvíce studenti polských středních škol. Ovšem při podrobném porovnání je patrné, že rozdíly při používání mobilních telefonů mezi studenty z jednotlivých států nejsou velké rozdíly (tab. 2).

Otázka: Když při vyučování podvádíte, používáte smartwatch (chytré hodinky)?

\begin{tabular}{|l|l|l|l|}
\hline $\begin{array}{l}\text { Smartwatch } \\
\text { (chytré hodinky) }\end{array}$ & Česko & Slovensko & Polsko \\
\hline \hline téměř vždy & 2,4 & 1,9 & 15,2 \\
\hline často & 1,2 & 5 & 4,5 \\
\hline občas & 7,1 & 6,6 & 4,5 \\
\hline zǔ́dka kdy & 6 & 10,3 & 16,7 \\
\hline nikdy & 83,3 & 76,2 & 59,1 \\
\hline
\end{tabular}

Tab. č. 3: Využivání chytrých hodinek při školním podvádění v \%.

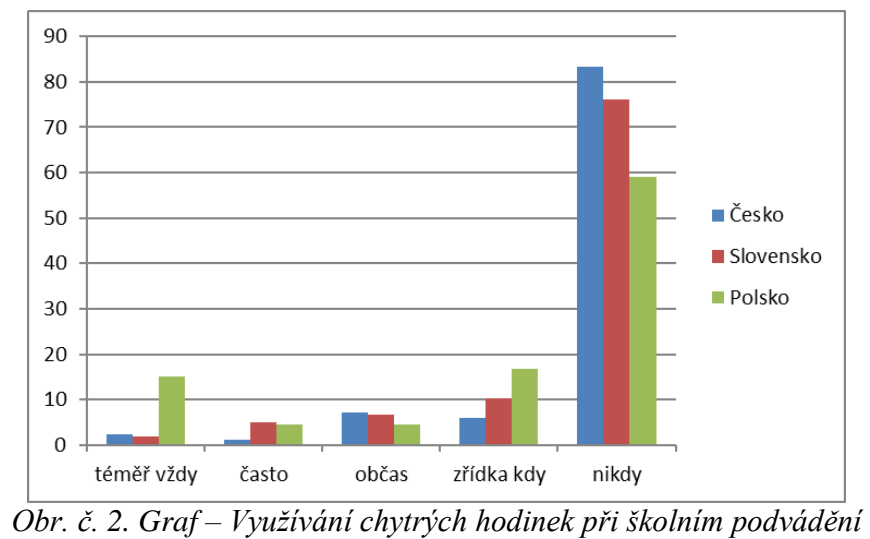

Výsledky dotazníkového šetření ukázaly, že v průměru $16,1 \%$ studentů využívá při školním podvádění smartwatch - chytré hodinky.

Z grafu a tabulky vyplývá, že nejvíce, jako nástroj podvádění, používají chytré hodinky polští studenti, nejméně studenti z Čech (tab. 3).

Otázka: Když při vyučování podvádíte, používáte klasický papírový tahák? 


\begin{tabular}{|c||c|c|c|}
\hline $\begin{array}{c}\text { Papírový } \\
\text { tahák }\end{array}$ & Cesko & Slovensko \\
\hline téměř vždy & 8,3 & 12,5 & 19,7 \\
\hline často & 25 & 22,7 & 19,7 \\
\hline občas & 25 & 23,2 & 16,7 \\
\hline třidka kdy & 19 & 23,8 & 16,7 \\
\hline nikdy & 22,6 & 17,8 & 36,4 \\
\hline
\end{tabular}

Tab. č. 4: Využiváni papírového taháku při školním podváděnív\%

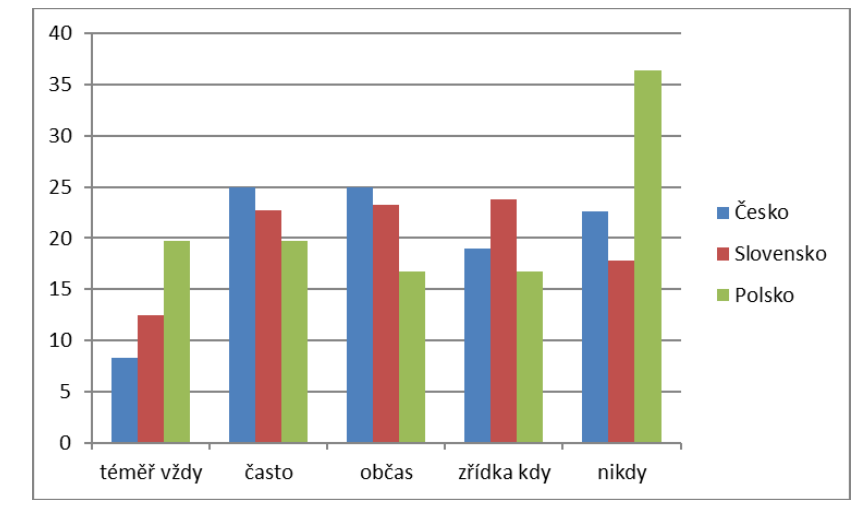

Obr. č. 3: Graf-Využiváni papírového taháku při školním podvádění

Výsledky ukázaly, že v průměru 57,6 \% studentů používá při školním podvádění papírový tahák, at' již vlastnoručně napsaný, či v tištěné formě převzatý. Podle zjištěných dat, používají papírové taháky ponejvíce čeští studenti. Ovšem jako u používání mobilních telefonů, rozdíly četností nejsou u jednotlivých skupin velké (tab. 4).

\section{Shrnutí výsledků a diskuse}

V této výzkumné studii byly prezentovány pouze výsledky vztahující se $\mathrm{k}$ ověření jedné hypotézy

H - Studenti středních škol využívají při školním podvádění více digitální technologie (mobilní telefon, smartphone, smartwatch - chytré hodinky) než papírové taháky.

Pro potvrzení či vyvrácení hypotézy srovnáme procentuální zastoupení četností jednotlivých kategorií. V našem př́ípadě nebudeme rozlišovat mezi respondenty z Čech, Slovenska či Polska. Hledáme pouze rozdíl v četnostech podvádění za pomocí digitálních technologií a klasického papírového taháku. 
Z tabulky 5 vyplývá, že $57,6 \%$ studentů, kteří ve škole podvádějí, používá klasický papírový tahák, 44,4\% mobilní telefon a 16,1\% smartwatch - chytré hodinky. Celkem tak digitální technologie získaly $60,5 \%$.

\section{Porovnání}

\begin{tabular}{|l|l|}
\hline Mobilní telefon & $\mathbf{4 4 , 4} \%$ \\
\hline Chytré hodinky & $16,1 \%$ \\
\hline Psaný papírový tahák & $57,6 \%$ \\
\hline
\end{tabular}

Tab. č. 5: Porovnáni nástrojů podvádění v \%

Ovšem naše výzkumná otázka zněla, zda studenti používají při školním podvádění více digitální technologie nebo papírové taháky, a proto je nutné při konečné prezentaci výsledků sloučit odpovědi studentů, kteří používají mobilní telefony a smartwatch - chytré hodinky a porovnat $\mathrm{s}$ četnostmi odpovědí studentů, kteří používají klasické papírové taháky.

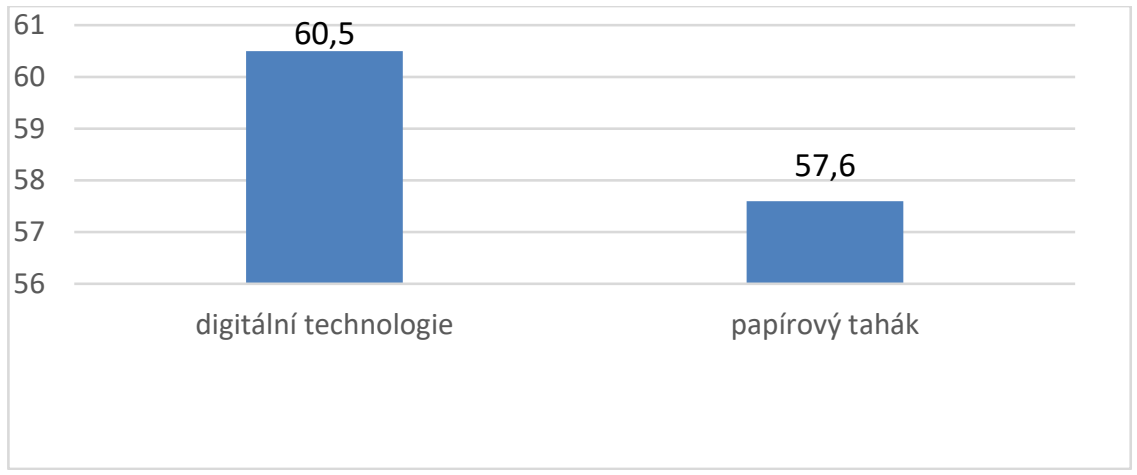

Obr.č.4: Graf-Porovnáni nástrojů podvádění v \%

Pokud za digitální technologie budeme považovat mobilní telefony a smartwatch - chytré hodinky, dojdeme k závěru, že studenti používají při školním podvádění více digitální technologie než papírové taháky.

\section{Hypotéza byla potvrzena.}

Dotazníkovým šetřením bylo zjištěno, že studenti při svém podváděním za účelem získání lepších výsledků při studiu používají ponejvíce psané či jinak připravené papírové taháky v porovnání s jednotlivými dalšími technologiemi. 57,6 \% studentů přiznalo, že takový tahák používají téměř vždy, často nebo občas. Podle zjištěných dat, používají papírové taháky ponejvíce čeští studenti. Mobilní telefon, jako nástroj školního podvádění používá téměř vždy, často nebo občas pouze $44,4 \%$ studentů. A ještě méně studentů používá téměř vždy, často nebo občas smartwatch - chytré hodinky, jedná se o pouze o 
16,1 \% dotazovaných studentů z České republiky, Slovenska a Polska. Chytré hodinky používají ponejvíce studenti z Polska, jedná se o téměř čtvrtinu studentů, kteří přiznali, že je používají téměř vždy, často nebo jen občas. Ovšem jako u používání mobilních telefonů, rozdíly četností nejsou u jednotlivých skupin velké.

Jelikož se jednalo o velmi rozsáhlý výzkum, byly zjištěny i četnosti dalších forem a metod školního podvádění, ale i např. kam si nejčastěji studenti papírový tahák ukrývají. Tyto výsledky budou průběžně publikovány. Zajímavé byly i názory studentů na školní podvádění a výčet motivů, které je $\mathrm{k}$ tomu vedou. Jako nejčastější důvod podvádění uváděli studenti stres ze zkoušení a nedostatek času na př́pravu. K podobným výsledkům došli i ostatní autoři (Mareš, 2005, Vrbová, 2013; Garavalia et al., 2007).

\section{Závěr}

Školní podvádění je považováno za nežádoucí jev na školách všech typů a stupňů. Jak ale zamezit tomuto nežádoucímu jevu, je opravdu složitá otázka. Samozřejmě, že nejjednodušší a nejefektivnější by bylo zamezení vzniku tohoto jevu, tzn. vytvořit takové podmínky, aby studenti neměli důvod podvádět, např. aby nebyli by ve stresu z nezvládnutí učiva a z hodnocení vědomostí. Domníváme se ovšem, že za současné organizaci školní výuky je to téměř nemožné. Účinnější by mohla být komplexní a systémová strategie, která školní podvádění jednoznačně odsoudí, sjednotí postup učitelů proti podvádění a vštěpí žákům postoj, že čestnost je jednou z nevýznamnějších lidských vlastností (Bajtoš, Marhenková, 2016). V praxi by to znamenalo vytvořit jakýsi etický kodex žáka. Druhým krokem by mohlo být zavedení preventivní strategie ze strany učitele, jejíž cílem by bylo úplně či alespoň částečně zamezit studentovi ve školním podvádění. Mezi tato opatření by mohlo být zahrnuto např.

- informovanost studentů, tzn. jak bude zkoušení a hodnocení probíhat, co se bude od žáka vyžadovat, jak se bude postupovat při odhalení podvádění, tyto navržené postupy dodržovat,

- $\quad$ zpř́snit postihy za podvádění,

- připravit více variant písemek, aby se nedalo opisovat či předem připravit,

- rozesadit studenty, rozdělit do skupin,

- vyzvat studenty, aby sklidili vše z lavic,

- průběžně lavice a studenty kontrolovat, nedělat během písemného zkoušení jiné činnosti (Bajtoš, Marhenková, 2016).

Zajímavá myšlenka týkající se snížení podvádění, je uvedena od Dr. David Rettingera (Brown, D., 2019, December 16) v př́spěvku týkajícího se podvádění. Podle uvedeného autora může být řešením častější používání testů kratšího rozsahu. Kratší rozsah testu nedává studentům čas $\mathrm{k}$ přemýšlení nad tím, jak podvádět či provést podvod př̀ testu a rovněž kratší testy nekladou tak velký tlak na studenta jako velké souhrnné testy. Článek však nabízí i další řešení, které jsme již také zmínili. Závěrem článku je tak myšlenka, že by studentům mělo být vysvětleno, proč by podvádět neměli. Metodu kratších testů však nelze aplikovat vždy, a to např́klad u maturitních zkoušek. 
V dnešní době je ale i možné školnímu podvádění zabránit rovněž pomocí digitálních technologií. Některé tyto formy kontroly však hraničí s narušováním soukromí (GDPR), jsou neetické či porušují zákony ČR. V některých zemích (Čína, Korea, Indie) jsou již ale hojně využívané. Může se jednat např́ílad o tyto formy kontroly studentů:

- lokální rušička mobilního signálu (levné, velmi účinné, avšak v ČR v rozporu s $\S 100$ odst. 1 zákona č. 127/2005 Sb., o elektronických komunikacích)

- monitorování studentů při psaní testů za pomocí kamerového systému (vy̌̌ší náklady, vyšší náročnost na další pracovníky)

- detektory bezdrátového signálu (vy̌šsí náklady, vyšší náročnost na další pracovníky).

Zpětná detekce školní podvádění je většinou velmi složitá. Vodítkem pro učitele může být např́íklad skutečnost, že student napsal písemnou práci výrazně lépe, než by odpovídalo jeho dosavadním výsledkům, či učitel zjistí shodu s jinou studentskou prací (většinou stejné chyby), anebo rozpozná doslovný text z knihy.

\section{Literatura}

Bajtoš, J., \& Marhevková, A. (2016). Školské podvádzanie - problémový aspekt hodnotenia výkonov žiakov. Bratislava: Wolters Kluwer.

Bajtoš, J., \& Honzíková, J. (2019). Školské podvádzanie z pohl’adu učitel’ov - pilotné výskumné šetrenie. Arnica - Acta Rerum Naturalium didactica, 2019(2), 51-58. Dostupné z: https://www.arnica.zcu.cz/images/casopis/2019/Arnika_2019_2-1-Bajtos-Honzikovaweb.pdf

Bernardi, R. A., Baca, A. V., Landers, K. S., \& Witek, M. B. (2008). Methods of Cheating and Deterrents to Classroom Cheating. International Study. Ethics \& Behavior 18(4), 373391.

Brown, D. (2019, December 16). Students are still using tech to cheat on exams, but things are getting more advanced.

Dostupné z: https://eu.usatoday.com/story/tech/2019/08/16/how-teachers-preventinghigh-tech-cheating-classroom/2017389001/

Clark, K. (2008). Taking a Bite Out of Cheating, With the Help of Technology. U.S. News \& World Report.

Cibulková, A. (2013). Podvádění očima středoškolských učitelů. Brno: Masarykova univerzita.

Cizek, G. J. (2003). Detecting and Preventing Classroom Cheating: Promoting Integrity in Assessment. Experts in Assessment. Thousand Oaks: Corwin Press, Inc., CA.

Honzíková, J., \& Bajtoš, J. (2019). Školní podvádění a IKT. Inovace a technologie ve vzdělávání. 2019(1), 15-22.

Eisenberg, J. (2004). To Cheat or Not To Cheat: Effects of Moral Perspective and Situational Variables on Students' Attitudes. Journal of Moral Education 33(2): 163-178. Garavalia, L., Olson, E., Russel, E., \& Christensen, L. (2007). How The Students Cheat? In Anderman, E. \& Murdosck, T. (eds) Psychology of Academic Cheating (33-55). Boston: Academic Press, Amsterdam. 
Kumar, M. J. (2012). Honestly Speaking about Academic Dishonesty. IETE Technical Review, 29, 357-358.

Mareš, J. (2005). Tradiční a netradiční podvádění ve škole. Pedagogika 55(4): 310-335.

Norman, J., \& Harris, M. W. (1981). The private life of the American teenager. California: Wade.

Simkin, M. G., \& McLeod, A. (2010). Why Do College Students Cheat? Journal of Business Ethics 94(3): 441-453.

Vrbová, J., \& Stuchlíková, I. (2012). Školní podvádění starších žáků: pilotní studie. Pedagogika, 62(3), 317-331. 